\title{
INTERNAL FACTORING REALITIES AND PERSPECTIVES IN ROMANIA
}

\author{
Lecturer Ph.D. Daniela-Marinela Manea, marinelamanea@yahoo.com \\ Lecturer Ph.D. Rada Postolache, radapostolache@yahoo.com \\ „Valahia” University, Târgoviste
}

\begin{abstract}
Summary: Among the most frequent techniques of financing the internal commerce, which do not have the attribute of a traditional banking credit, there are to be found factoring operations. Thus, the economic and judicial practice has designed a technique of offering a particular credit on a short or medium term to the trader, producer, and also the services provider. Briefly, this would be the essence of factoring, as a technique of commerce financing.

The work in question is aimed at analyzing those elements specific to the factoring contract, by confronting the economic dimension with the juridical one, at a national level, without omitting at the same time the international context, so as to create a synoptic image of the aspects, procedures and statistical data typical to internal factoring.

On the basis of the statistic information, one of the most important objectives is that of establishing the exact circumstances in which the internal factoring contract is used as a credit instrument, not only by commerce operators but also by credit institutions.
\end{abstract}

Introduction. The freedom of commerce, in its modern dimension, has led to the expansion and the variation of contractual forms resorted at by economic operators, with the view of maximizing their profit. The variety and the development of commercial contracts but also the surge of goods and services exchanges are underlining more and more the need of financial means. Commercial flows have always been supported by other economic resources than their own; considering the current development of the financialeconomic relations at the internal level, more attention is being paid to the credit issue in particular and to commerce financing in general.

Each commerce activity is financed particularly with the credit offered by credit institutions, traditionally banks. Financing a commerce activity by resorting to the banking credit mechanism, often represents a disadvantage for the commerce operator, who, in most of the cases, has to provide concrete guarantees to the credit bank (either movable or real), or collateral deposits, according to the banking laws; moreover, especially when it comes to short-term credit needs, the commerce operator is not always willing to immobilize his guarantees by resorting to a banking credit.

For this reason, the commerce practice has imagined what often the law has provided, that is other techniques of financing commerce activities. They are aimed at offering a particular credit, on a short, medium or long-term, according to the case, which is not accompanied by the guarantees usually required by banks when giving a traditional banking credit; this way there could also be explained the particularity of the settlement mechanism and its effects.

Since what they offer is essentially a type of credit, these techniques presuppose as well costs specific to the latter. Given the fact that we are not talking about a traditional banking credit, these financing techniques can be practiced by banks and also by other structures which do not abide by the rules ensuring the organization and the functioning of credit institutions. Among the most frequent techniques of financing the internal commerce, which do not have the attribute of a traditional banking credit, there are to be found factoring operations. Thus, the economic and judicial practice has designed a practice of offering a particular credit on a short or medium term to the trader, producer and also the services provider. 
Briefly, this would be the essence of the factoring as a financing commerce technique. Currently, the structured financing market, previously exemplified with the respective particular credit, is taking an upward direction, as a result, on the one hand, of the undertaken surveys regarding the specific procedures of accessing and using factoring not only by factors, but also by potential adherents and, on the other side, as a result of the growing need of making the economic activity more efficient, when it comes to resorting to those financing techniques which are the easiest to access.

Thus, despite the development of the demand and supply of products of structured financing, there still continues to be a considerable gap between the Romanian factoring market and the European one. Consequently, there are necessary a thorough analysis of factoring mechanisms, a study of the data existing at a national level (taking at the same time into account the international economic relations), and the popularization of the financing product, so as for the debtor and the creditor to achieve benefits.

That being the case, the work in question aims at analyzing those elements specific to the factoring contract, by confronting the economic dimension with the juridical one, at a national level, without omitting at the same time the international context, so as to create a synoptic image of the aspects, procedures and statistical data typical to internal factoring.

On the basis of the statistic information, one of the most important objectives is that of establishing the exact circumstances in which the internal factoring contract is used as a credit instrument, not only by commerce operators but also by credit institutions; the present analysis focuses on the factoring department of Raiffeisen Bank Romania.

In Romania, factoring is not regulated by special laws, being consequently subject to the civil law; yet, it is being used on a constantly larger scale by credit institutions, particularly banks, on the basis of the internal technical regulations; the latter aim at ensuring a clear and complete background as possible, suitable for the development of credit activity in good conditions, by means of this particular type of commercial credit.

\section{A juridical approach}

We shall analyze only those elements relevant for the factoring contract, in connection with the theme in discussion; juridical regulation, concept, persons involved in the juridical factoring relation.

\subsection{The judicial regulation}

Similarly to other modern contracts, the factoring contract has become part of the Romanian business only after 1990; it is a relatively recent contract, a creation of the commercial practice, more precisely of the banking branch. The normative act of maximum generality is represented by the provisions of the Government Emergency Ordinance no. 99/2006 regarding credit institutions and the social capital adequacy ${ }^{l}$, which mentions the activities allowed to credit institutions, including factoring (art. 18, paragraph 1). Factoring is part of the credit operations group (letter b), which includes, among others, consumer credits, mortgage credits, factoring with or without regress, the financing of commercial transactions, including forfaiting. Among the general applicable regulations, there are also the provisions of the Law no. 469/2002 regarding a series of measures taken for consolidating the contractual discipline ${ }^{2}$; yet the law concerns a larger field of this and not exactly the essence of factoring.

Neither in the Romanian law system, nor in the Community Law, is there a special regulation completely focusing on factoring. Law is generous and serves banking liberalism. The

\footnotetext{
${ }^{1}$ Off. Gaz., Part I, no.1027, 27th December 2006, currently called Government Emergency Ordinance no. 99/2006.

${ }^{2}$ Off. Gaz, Part I, no. 529 of 19th July 2002, modified through the Government Emergency Ordinance, no. 112/2002. Off. Gaz., Part I, no. 404 of 26th November 2002, approved with adjustments through the Law no. 647/2002, Off. Gaz., Part I, no. 909 of 13rd December 2002 and through the Law no. 416/2006, Off. Gaz., Part I, no. 946 of 23rd November 2006.
} 
specific juridical regulations regarding the factoring contract are brief, enough to delimit the factors field and the object of the factoring contract.

Yet, there are not to be ignored the professional regulations within the field. The absence of some complete specific regulations and the permissiveness of those already existing have encouraged banks to elaborate a series of internal norms ${ }^{3}$ regarding factoring. Among the most important ones there are the factoring framework agreement and the general and specific conditions regarding factoring contracts. Although every bank makes its own rules, their internal norms are quite similar, that is why we can talk about the existence of a common banking practice, of a customary law within the field, not codified yet. Factoring continues to be a result of the permissiveness within the field, where the creation of banking technique feels at home.

In 1998, at Otawa, under the care of UNIDROIT, there was internationally adopted the Convention concerning international factoring, which is applied in regard with the international juridical relations and which was also taken into account by Romania when setting its brief internal specific regulations. The Convention becomes of interest if, in some concrete circumstances, the parts have alluded to it. We shall not illustrate here its provisions or the differences between internal and international factoring, given the theme of the work in discussion.

In conclusion, the commercial features and the absence of some specific regulations ascribe the factoring contract to the general conditions of existence and validity of commercial contracts, which exceed this analysis and do not require special approaches.

1.2. Notion. In what the "consolidation of contractual discipline" is concerned, factoring is regulated as a "debentures mobilization mechanism", together with or as an alternative of guaranteed payment instruments (payment order, certified cheque, bill of exchange, ticket at order, authorized by a banking society and previously accepted by the principal debtor, under the provisions of the particular law).

According to the Law no. 469/2002, article 6, paragraph 2, letter b, factoring represents a contract between one part called adherent - provider of goods or services - and a banking society or a specialized financial institution, called factor, by means of which the latter ensures the financing, the debt monitoring and the protection against credit risks, while the adherent assigns (sells) to the factor the debentures resulting from the selling of goods or the services provided to a third person.

According to the law in discussion (article 6, paragraph 1), factoring can be defined as a debentures mobilization instrument, the effect of which is the accomplishment of the payment ${ }^{4}$ by the contracting parts.

There is in the juridical literature ${ }^{5}$ an accredited definition, close to the nature and the objective of such a juridical instrument, which goes like this: "factoring represents the contract between two persons, stipulating the fact that one of them - the factor - in the exchange of a certain commission, takes up the commitment of cashing all the debentures (bills, documents attesting the providing of a service) which the other part - the adherent (seller, provider) - has to transmit him in exchange for money, therefore subrogating ${ }^{6}$ the factor from all his rights.

Within the juridical practice, factoring is frequently included in the financing techniques category. Yet, given the juridical techniques that it makes use of, factoring detaches itself from the traditional credit, which mainly presupposes offering funds; essentially, it represents "a credit

\footnotetext{
${ }^{3}$ Banks have to elaborate internal norms for working, which are secret, not made public, and which offer details about the requirements and the conditions of their activity, on the basis of the provisions of the Government Emergency Ordinance no. 99/2006.

${ }^{4}$ Taken from the main contract: adherent-assigned debtor.

${ }^{5}$ Octavian CAPATANA, Brandusa STEFANESCU, Dreptul comertului international, volume II, Academia Romana Publishing House, Bucharest, 1987, p. 249-252.

6 The banking law allows factoring ,with or without regress”. It is essential the qualification ,with or without regress” becuase each of the two categories triggers different juridical effects.
} 
through a debenture transfer", delegation, personal subrogation by payment. The adherent sells its bills to the factor (usually a bank) for e certain amount of money, at the nominal value of the bills or for a lower price. All the risks, including that of insolvency, become the responsibility of the factor, who has no right of regress on the adherent.

Establishing the identity of factoring requires two aspects: separating factoring on the one hand from the traditional operations which define it - debenture assignment, personal subrogation by payment, delegation, mandate and, on the other hand, from the operations which aim at obtaining a credit - granting a credit, giving short-term credits which are guaranteed with debentures plus the order confirmation ${ }^{8}$, the discount, the forfaiting ${ }^{9}$ (all of these are generically called connected juridical institutions ${ }^{10}$, but are not the object of the analysis in discussion)

We consider the factoring contract a composite one, including perations and techniques which belong to different contracts, so that it cannot be limited only at one of these. Within the Romanian law, factoring represents a contract without a name, particular and complex, which combines more than one operations. It has a well distinguished identity and is concluded so as to put into practice another contract, a fundamental one, between the adherent and the assigned debtor, just like in the case of most banking contracts.

1.3. The participants at the factoring technique. Factoring constitutes a complex contract, which brings together three persons - parts of distinct juridical relations - and which involves at the same time specific rights and obligations: the juridical relation adherent - factor (factoring itself), the juridical relation supplier (adherent) - beneficiary (assigned debtor), the juridical relation factor - assigned debtor. Jut like in the case of most banking contracts, there can be noticed the existence of a complex tripartite juridical relation, with the greatest interest coming from the adherent and the factor, and not from the assigned debtor, the latter being fine with whomever has to give money. The notification of the debenture assignment only aims at letting know the assigned debtor that he has to pay the assigned debentures to the new creditor - the factor.

The Adherent. The subject who initiates the business is the adherent, a name taken from the international regulations - the Convention regarding International Factoring, Otawa, 1998. He is a trader whose function is to perform commerce activities, that is producing and trading goods, or only trading goods, on his own and under his name, or providing services. There is the opinion ${ }^{11}$ that, in what the Romanian law is concerned but more precisely the internal factoring contract, the attribute of adherent could be assigned as well to those juridical persons who, without being traders, have, according to the law, the recognized capacity of performing commercial activities. There are included here the co-operative societies provided by the Law no. 1/2005 (regarding the organization and the functioning of the co-operative society ${ }^{12}$ ), the agricultural co-operative societies constituted according to the Law no.556/2004 (the law of agricultural co-operative society ${ }^{13}$ ), and the agricultural societies constituted as civil societies with juridical character, according to the Law no. 36/1991 (regarding agricultural societies and others forms of association in agriculture ${ }^{14}$ ). According to the same opinion, the attribute of adherent can be assigned as well to some juridical

\footnotetext{
${ }^{7}$ For the credit classification, Ion TURCU, Operatiuni si contracte bancare. Tratat de drept bancar, Vth edition, amended, vol. 2, Lumina Lex P. House, 2004, p. 247-249.

${ }^{8}$ For more information, Brîndusa VARTOLOMEI, Contractul de factoring, Lumina Lex Publishing House, Bucharest, 2006, p. 117-161.

${ }^{9}$ For a brief analysis, Brandusa STEFANESCU, Dreptul comertului $i$ nternational, Course Notes, the Faculty of Juridical Sciences, ”Valahia” University of Targoviste, 2003.

${ }^{10}$ Brîndusa VARTOLOMEI, quoted work, p. 117-161.

${ }^{11}$ Idem.

12 Off. Gaz., Part I, no.172 of 28th February 2005.

${ }^{13}$ Off. Gaz., Part I, no. 1236 of 22nd December 2004.

${ }^{14}$ Off. Gaz., Part I, no.97 of 6th May 1991.
} 
entities such as associations and foundations ${ }^{15}$, to which the law recognizes the capacity of carrying out economic activities, such as the sale of goods or the services providing; at the same time, it is not excluded for the quality of adherent within a factoring contract to be assigned also to an autonomous administration, a juridical person representing the public law, according to the Romanian law ${ }^{16}$, if the activity of that person includes the sales of goods and the services providing.

Practically speaking, banks frequently work with commercial societies as adherents, taken into account the fact that their internal norms promote this direction. Their customers are mostly traders, and they are very well aware of their financial situation, given the field in which they work.

Taking into account the ground of the factoring contract, in which both parts are interested, and the frequency of the accomplished operations, we consider it absolutely necessary fr the adherent to have the attribute of juridical person, and for those economic activities generally called "sale of goods and services providing" to take place.

The physical person can transmit his juridical obligation by means of assignment, but the operation is governed by the provisions of the Civil Code and cannot be ascribed to the factoring pattern.

The Factor. Unquestionably, factoring is a technique of debentures mobilization, being integrated, through its function, to the credit $^{17}$ - generally regulated by the Government Emergency Ordinance no. 99/2006, article 8, paragraph 1, letter b. Is factoring an activity exclusively dedicated to credit institutions? Can it be practiced by some different entities as well? On what conditions? Delimiting the field of factors requires an analysis of the existent juridical background and also of the immediate goal of factoring operations.

According to article 18, $1^{\text {st }}$ paragraph, letter b) of the Government Emergency Ordinance no.99/2006, credit institutions can carry out, under the limits of the authorization received, the following activities: giving credits, including, among others: consumer credits, mortgage credits, factoring with or without regress, and financing the commercial transactions, including forfaiting. According to the same regulation previously mentioned, article $7,1^{\text {st }}$ paragraph, point 10 , letter a), the credit institution is by definition "an entity having the task of attracting deposits or other reimbursable funds from the public and giving credits on its own." According to the law, the credit institutions category includes: banks; co-operative credit societies; saving and credit banks within the living domain; mortgage credit banks; institutions issuing electronic coin. (art. 3).

The Law no. 469/2002 regarding some measures taken for consolidating the contractual discipline, article 6, paragraph (2), limits the factor to a "banking society or specialized financing institution". Since the Law no.469/2002 does not offer any definition of the financing institution, there should be reminded the definition given by the basic regulation - the Government Emergency Ordinance no. 99/2006, article 3, $1^{\text {st }}$ paragraph, point 14: "an entity, other than the credit institution, the main activity of which consists participating at the social capital of other entities or carrying out one or more activities of those provided by article $18,1^{\text {st }}$ paragraph, letter b)-1)"

Therefore, according to the two regulations previously discussed, the quality of factor can be undertaken by credit and specialized financing institutions. Among credit institutions, those which cannot have the quality of factor are the institutions issuing electronic coin, given the fact that they are specialized precisely in this domain; practically, their object of activity is limited only at issuing electronic coin, so that they are forbidden to give credits, irrespective of the form of the credit (article 321, article 323, Government Emergency Ordinance no.99/2006). In what financing institutions are concerned, although they are capable of performing all those operations provided by

\footnotetext{
${ }^{15}$ Constituted according to the Government Ordinance, no. 26/2000, Off. Gaz., Part I, no. 39 of 31 st January 2000, approved with adjustments through the Law no. 246/2005, Off. Gaz., Part I, no. 656 of 25th July 2005.

${ }^{16}$ Constituted according to the Law no. 15/1990 regarding the reorganization of state economic units as autonomous administrations and commercial societies, Off. Gaz., Part I, no. 98 of 8th August 1990.

${ }^{17}$ For more information, Rada POSTOLACHE, Drept bancar, Cartea Universitara P.House, Bucharest, 2005, p. 179182.
} 
article $18,1^{\text {st }}$ paragraph, letter b)-1), of the Government Emergency Ordinance no.99/2006, the law itself impose them restrictions, invoking the condition of their particular character. Since the law says no more, we consider that these institutions have to be specialized in factoring operations and be factoring operations, accordingly authorized.

The limitation of the factors field is motivated as well by the reasons for which factoring contracts are concluded. With its function, factoring is integrated to credit and is referred to credit and financing institutions, which are strictly regulated by the Government Emergency Ordinance 99/2006 and monitored by the National Bank of Romania. Therefore, factoring institutions are limited, so that they cannot be different from credit and financing institutions. Moreover, credit institutions, through their particularities and massive capitalization, can regularly accomplish the commitments undertaken and can get to know closely their customers' customers.

If were to accept factoring only with its initial functions of ensuring the debentures mobilization and offering protection against credit risks, then factoring could be performed by any other entity which has the interest, the competence and the courage of taking up risks, especially that the protected persons are particularly the adherents and not the banks' customers, lato sensu.

To conclude, according to the law, banks and financing institutions can act as factors, so as to cover together "the financing, the debentures mobilization and the protection against credit risks."

According to the proposed approach, we shall treat the factor exclusively between the normative limits characteristic to the respective state of credit institutions. Just like the international practice has pointed out in the case of the most developed countries, such as the United States of America, England, France, Belgium or Sweden, factors are constituted as specialized commercial societies, respectively as factoring societies. In the same countries mentioned above, commercial banks have generally constituted in parallel their own departments specialized in factoring operations, included in their own organizational chart.

In Romania, factoring operations have been so far carried out mainly by commercial banks, there being only one society specialized in factoring, which exclusively performs this kind of operations. It is the case of the Factoring Company IFN S.A. (society of shares), member of Factor Chain International $(\mathrm{CFI})^{18}$. It is a specialized society, having as main shareholders, in a proportion of $50 \%$, Internet Bank Austria (Viena) and the Transilvania Bank of Romania ${ }^{19}$.

Actually, the recent regulations - the Government Emergency Ordinance no. 99/2006 regarding credit institutions and the social capital adequacy, and the Government Ordinance no.28/2006 regarding the regulation of some fiscal financial measures, do not provide the setting up of some commercial societies to have factoring operations as a single object of activity.

The Assigned Debtor. The assigned debtor is involved in the factoring relation by paying the debentures sold to the factor when they reach maturity. The role of assigned debtor may be assumed as well, without any exception, by a trader or commerce operator, the latter notion including juridical persons from the private law field who do not have the quality of traders, but who are allowed by the law to elaborate commerce documents, independent goods buyers or services beneficiaries. Assigned debtors may also become the traders (physical or juridical persons) and those entities without juridical personality to which the law recognizes the capacity of concluding commerce documents and the right to justice for these documents. Just like in the case of the adherent, we will only take into consideration the juridical quality of the assigned debtor. When performing his commercial activity, the debtor has to buy the goods from the adherent or to benefit from the service provided by the adherent. It cannot be considered debtor the person who gets goods and services as a final consumer, with personal title, for personal use, or the person who does

\footnotetext{
${ }^{18}$ It is the case of the Factoring Company IFN S.A.

${ }^{19}$ It is estimated for the Romanian factoring market, which currrently is not quite well developed, in comparison with other states (eg. Slovenia), to make progresses in the next two years, reaching an ammount of 2 milliards Euro.
} 
not have the quality of a trader, so that the contract between the respective person and the seller or the services provider is in this case an assigned civil or administrative contract. ${ }^{20}$

\section{The Economic Approach}

Factoring represents the operation by means of which the client, called adherent, transfers the property of his bills to the bank, called factor, the bank having the obligation, according to the concluded contract, of cashing the customer's debentures, taking up also the risk of a potentianl non-payment. On the basis of the received documents, the bank pays the nominal value of debentures, except for the agio ${ }^{21}$, either immediately or at the maturity ${ }^{22}$. When it comes to giving a credit to a juridical person, the banking society takes into account, on the one hand, various aspects regarding the respective customer's financial-economic situation, while on the other hand some elements which can define the nature of the activity performed by the economic agent, in order for him to obtain a certain position in the hierarchy of the economic field in which he works.

\subsection{The Methodology of the Factoring Contract at Raiffeisen Bank Romania}

We have chosen to analyze factoring at Reiffeisen Bank of Romania, since it is a bank in a continuous development, among the first banks to have come over the difficulties which are inevitable when adopting the new banking system Raiffeisen Bank is the follower of the Agricultural Bank of Romania, the first bank with state capital to be privatized. Its customers come from different fields, not only from the agricultural one. According to its regulations, factoring represents a post-delivery financing product on a short-term, an alternative to standard credits ${ }^{23}$.

As a factor, Raiffeisen Bank can perform at least two of the following services:

- Financing at most $80 \%$ of the value of the bills issued by the eligible debtors;

- Administrating debentures;

- Collecting debentures at maturity;

- Offering protection against the risk of non-payment (factoring without appeal)

The advantages offered to customers consist in:

- The payment at term becomes a payment at sight, increasing the amount of liquidities held by the customer;

- The amount given can be used according to the customer's necessities, without a particular direction being imposed;

- Mo material guarantees are required;

- Protection is ensured against the risk of a non-payment of the eligible debtor (in the case of factoring without appeal)

The fiscal treatment of factoring. According to the provisions of the article 141, paragraph 2, letter a), point 3 of the Fiscal Code ${ }^{24}$, factoring operations are subject to the taxation by the Value Added Tax (VAT), while the factor has the obligation of collecting the VAT owed to the adherent for these factoring operations. Therefore, the factoring and the processing commissions will be subject to the taxation by VAT both in the case of factoring with appeal and the factoring without appeal. The discount tax (the interest) will be subject to the taxation by VAT only in the case of the factoring without appeal.

\footnotetext{
${ }^{20}$ For more information, Brîndusa VARTOLOMEI, quoted work, p. 175. This aspect is also uphold by the provisions of article 19, point a) of the Factoring Framework Agreement, according to which "the factor registers a regress in front of the adherent, according to the provisions of the Civil Code, if occurs in any of the following circumstances: a) the adherent's debentures do not originate from a commerce act, in the sense of article 3 of the Romanian Commercial Code, but from a civil, administrative, penal or different act.

${ }^{21}$ The a mmount deducted by the factor from the nominal value of the assigned debentures, under the limit of $20 \%$, with guarantee title, until the transferred amounts to the assigned debtor are cashed.

${ }^{22}$ Elena ZAHARCIUC, Contabilitatea societatilor bancare, Teora P.House, Bucharest 2000, p. 154.

${ }^{23}$ Norms and procedures "Factoring - a Product Presentation" Raiffeisen Bank Romania.

${ }^{24}$ Off. Gaz., Part I, no. 927 of 23th December 2003.
} 
The range of services offered by the factor is complex, but different, according to the nature of the transaction. In connection with the juridical commitment of the factor, there can be distinguished:

- The factoring with appeal, when the factor offers financing, administration and debentures collecting services

- The factoring without appeal, when the factor offers financing, administration and debentures collecting services and also covers the risk of a non-payment of the assigned debtor

According to the nature of commercial flows, there can be distinguished:

- The domestic factoring, a financial product dedicated to the internal market, which presupposes the discount with or without appeal of the debentures from bills issued by the assigned debtors, in the regard with the sale contracts signed with them;

- The export factoring, a financial product dedicated to exporters, which has to do with the discount with or without appeal of the debentures resulting from export contracts.

Domestic factoring represents a product dedicated to the internal market, which presupposes the discount with or without appeal of the debentures from bills ( maximum $80 \%$ of their value), issued by eligible debtors in regard with the sale contracts signed with them . This type of contract has the following objectives: financing at most $80 \%$ of the value of bills, administrating and collecting the bills issued according to the commercial contract, covering the risk of a non-payment of the assigned debtor (factoring without appeal).

Payments are performed on the basis of the following: the original bills (eg: those on red paper), carrying the mention of the subrogation and being accepted for payment by the assigned debtor, copies of delivery documents and also other documents, according to the case. The maximum maturity of bills is of 120-130 days, while the reimbursement takes place at the maturity of the bills, there being a tolerance period decided by the bank (at most 30 days). The objective of the factoring facility is that of financing a certain percentage (but not higher than $80 \%$ ) of the bills issued by the adherent for the eligible debtors. The bank will establish the eligibility of debtors through a due-diligence process, according to its standards and procedures. Payments will be performed after the following documents having been shown: a) commercial bills accepted by the eligible debtor; b) documents attesting the delivery/the services providing; c) other required documents.

For each payment connected to the credit facility, two days before the payment date, the adherent will show to the bank a payment acknowledgement and all the justifying documents ${ }^{25}$. Payments will be reimbursed at the maturity of bills, plus a tolerance period established by the bank (20 days). The discount tax is calculated according to the following formula: BUBOR, required for the accreditation period $+5 \%$, being collected at the processing moment. The discount commission is calculated as $0.5 \%$ of the total value of the facility, but it has to be of at least $300 \$$ or the equivalent of $300 \$$, integrally paid at the first payment. The processing commission is calculated as $0.5 \%$ of the payment amount, but it has to be equivalent with at least $20 \$$. The punishment interest will be collected in the case of some delayed payments, on a period between the maturity date and the effective date of payment. The punishment interest will correspond to an interest usually practiced by the factor for an account overdraft and will vary according to the market tendencies.

\subsection{The implications and tendencies of internal factoring}

\subsubsection{The benefits and disadvantages of the factoring contract}

The benefits of the factoring contract come from the inner advantages of this credit procedure, but also from the promising result obtained after comparing the positive aspects with disadvantages, the latter existing in a small proportion. In order to gain a synoptic picture of the necessity represented by the factoring contract against the background of credit products and also of the efficiency that this type of contract has achieved after being used by economic agents, the

\footnotetext{
${ }^{25}$ Norms and procedures "Factoring - a presentation of the product", Raiffeisen Bank Ro mania.
} 
present subchapter will illustrate for the start its strong points, in comparison with the less benefic elements.

The first advantage comes from the small number of the procedures required for obtaining the credit facility. For the start, the seller and the buyer conclude a commercial contract. The seller fills and hands in a standard printed form, by means of which he requires financing from the factor through factoring; apart from some general information (solicitor, object of activity, debtor, sales, imports etc.), the contract also contains some extra information about each client (name of the client, address, contact person, the register number at the Commerce Register, the fiscal code, estimated sales etc.) The factor analyzes and verifies the assigned debtors, communicating the preliminary amount, the costs and the conditions of factoring operations to the import factor. The last stage is the conclusion of the factoring contract between the seller (as adherent) and the commercial bank (as factor).

One of the most considerable aspects is the fact that the mobilization of debentures reaching maturity at the due moment takes place with a quantum of at most $80 \%$ of the total value of debentures, so that the difference is discounted at the maturity from the value of the payment made by the adherent through the factor, after the deduction from the interest value and the owed commissions. At the same time, there should be taken into account the fact that, by means of factoring, the adherent, by transmitting the debentures, performs an immediate and irrevocable cashing of nominal values (represented by bills) coming from the factor, the latter becoming the adherent's financing person, until the customer effectively pays all his bills. The customer has to deal with his monthly obligations towards the state budget, the renting expenditure, energy, water, salaries and also with the purchasing of considerable quantities of raw materials.

Factoring allows the adherent to benefit from the necessary capital for continuing the commerce, to reduce the rotation cycle of the fond de roulment by the immediate payment of bills by a single financing institution and not by the great number of customers, to focus his attention on the commerce itself and, last, to register a growth of the turnover and benefits. The period for obtaining liquidities is shorter than in the case of a credit, and also it is not necessary to maintain a certain destination for them. Moreover, the documents required for obtaining the financing through factoring are not as many as those necessary for obtaining a credit. There should be remembered the fact that the adherent can resort to factoring only for the debentures payable on a short-term (usually less than 120 days and only exceptionally 180 days), while the operation can be carried out also with appeal against the seller.

But one unquestionably strong point is that of eliminating the risk of insolvency potentially experienced by the commercial partner of the adherent, a risk like this being taken up by the factor. When it comes to the factoring without appeal, the factor take up this risk, thus eliminating the expenditure from the profits and losses account, involved by the risk of insolvency.

Coming in charge with the task called "customers" from the adherent's accounting, and making use of the current account system, factoring contributes at simplifying the accounting evidence of the adherent and also of his functional system of financial and accounting monitoring, regarding the cashing of bills; this way, the adherent can benefit from a reduction in the amount of the funds necessary for the current activity and from the possibility of using the financial means for other purposes. The factor carries out all the operations connected to the adherent's bills, processes these bills by introducing them in his informational system, together with their cashing. At the end of every month, the factor draws up a complex financial report regarding the operations performed.

Another aspect which should be mentioned is the fact that the financing expenditure on the whole is exclusively in the charge of the debtor, the latter having to support not only the financing cost (the interest), but also the value of the commissions charged by the factor. This contractual clause is not so important in comparison with all the advantages obtained when benefiting from a factoring contract. With the help of the factor, the adherent enjoys current facilities of treasury, either through the credits that he receives, or through the feeding of the current account with 
liquidities necessary to the current payment operations, and at the same time benefits from specialized banking services.

Taking into his responsibility the task "customers" from the adherent's administration, the factor becomes an administrator and a consultant of the adherent when it comes to selecting the customers according to their solvency and directing the adherent's commercial policy into a certain direction; yet, the adherent loses this way part of his financialeconomic independence. The involvement of the factor in the administration oh his customer's business - the adherent - is accompanied by a large spectrum of services, but also by some aspects connected to the modern methods of administration and accounting, by studies analyzing the foreign market or juridical services; all these are meant to make the adherent more operational, to strengthen his safety and to expand the market, by establishing relations with partners with a certain solvency.

The adherent can benefit from unlimited capital, factoring representing the only financing source through which financing grows together with the sales. As the turnover increases, amounts of money become available for meeting the surging demand for financing. The factor provides regular detailed reports, which allow a better administration of the cash-flow, and at the same time there are no geographic limits regarding factoring operations. The adherent takes a full advantage form the discounts received at the immediate payment (early payment discount) or for ordering large quantities of goods (volume discount). If a certain business can save between 2 and $5 \%$ of the cost of the raw materials necessary to production simply because the adherent has the required money for paying them within 10 days, then this aspect diminishes considerably the real cost of the financing through factoring.

By using factoring, the adherent no longer offers discounts for the immediate payment. As long as the sellers immediately cash their debentures, they will no longer have to offer discounts for the immediate payment. By making these savings and taking advantage from the discounts received for the immediate payment, the adherent is capable of compensating the factoring cost. Factoring operations are less expensive than building an own department for monitoring and collecting debentures. In a study from 2004, the Sofres Institute points that, in the first case, factoring commissions account in France between 0.5 and $2 \%$ of the turnover, while the costs for organizing a specialized department are at least of $2.5 \%$ of the turnover.

\subsection{Tendencies regarding factoring in the Romanian economy}

The current analysis is based on the statistic data furnished by the main factoring organizations. If at the beginning factoring was restricted only at financing the textile and clothing industry, in time it has expanded its spectrum towards some fields such as the production of sport items, toys, building materials, communications hardware and also towards hi-tech industries (computers, mobile phones, digital cameras etc.) The numerous swift changes within the business field create opportunities for selling the products on a larger scale. The progresses made by the information technology and transports have favored a change in the traditional limits of markets. This has lead to a speeding up of commercial exchanges in all geographic areas, and, in order to be competitive, companies have to offer flexible payment terms to their customers, the result being a strong need of financing resources. Thus, the growth of commercial operations is accompanied by a proportional growth of factoring operations.

One of the features of factoring industry is the fact that internal factoring accounts for most of the operations which are performed. Moreover, factoring operations without appeal are the most numerous among factoring operations. Throughout its long history, factoring industry has constantly adjusted itself to the changes, by developing new techniques, methods and efficient business instruments. These flexibility and capacity of adjustment will allow the factoring industry co continue to meet the financial needs of the companies in the future. In Romania, the financing through factoring of the activities of enterprises appeared at the middle of the 90s, and it can still be found in an intermediary stage, when it comes to banking societies or the way in which this type of financing is used by the enterprises. 
The Romanian factoring market is not currently developed at its real potential, either that we refer to its volume or to the societies providing such services, mainly because of the lack of experience and tradition which characterizes banking societies or the legal provisions within the field. For all the substantial advantages offered by factoring, Romanian firms have never resorted on a large proportion to this category of products until 2001. It was only then when transactions overcame 100 millions of euro. At the same moment, the amount of transactions in Poland was of 3.000 millions of euro. In the Czech Republic, Hungary and the Baltic countries, a superior amount was being registered as well. The reasons of such a gap are connected to the macroeconomic conditions and the supply of the banking system. The modest banking supply has been an impediment for factoring expansion, but the current tendency is that of accelerated growth. The rapid growth pace of the income made by banks as a result of factoring operations (about 10 times in the last six years) shows the intensification of commercial exchanges and the need of liquidities expressed by economic agents, who are confronted with a stronger and stronger competition. According to the statistic data, the amount of factoring operations performed in Romania in 2006 rose to 710 millions of euro, that is a growth of $29 \%$ respect to the previous year and of $36,36 \%$ respect to 1996 (19 millions of Euro). This aspect clearly proves that the Romanian factoring market is going through continuous changes. The share of internal factoring operations, estimated for the first semester of 2007, is about $54.5 \%{ }^{26}$ that is about 300 millions of euro. The development registered by this type of credit becomes even more obvious if thinking about the figures registered last year on the same period. In comparison with the first semester of 2006, there has been a growth of $71 \%$ of the value of internal credit contracts. The activity domains considered to be fit for factoring operations and taken into account by Romanian banking societies when selecting their customers are the following: forestry operations, glass, china, pottery, ready-made clothes, textiles, leather, footwear, furs, electronics, electrotechnics, household appliances, food industry, wood, cellulose, paper; there might also be included other fields as well.

Currently, the local market of factoring services is divided between the Romanian Development Bank (29\%), the Romanian Commercial Bank (25\%), UniCredit Tiriac, Raiffeisen(10\%), ABN Amro (12\%) and other societies. Taking into account the total value of factoring contracts at an European level, Romania has registered a growth of $21 \%$, from $0.076 \%$ to $0.092 \%$, so that its share of European credits remains, as it can clearly be noticed, at an extremely low level. The particular development potential that Romania has when it comes to factoring, is proved not only by its constant evolution in the last years, but also by its participation percentage at the total amount of factoring credits at the European level, similar to that of the countries from East and Central Europe. According to Factoring Chain International, Turkey registers a participation percentage of $1.84 \%$ at European factoring, while Hungary has a contribution of $0.35 \%$, Estonia of $0.36 \%$, whereas Slovakia of $0.16 \%{ }^{27}$. Moreover, according to the official statement made by the Romanian subsidiary of the most important company in the world dealing exclusively with factoring - Factoring Chain International - factoring contracts have reached a quantum of 1 milliard euro in 2006, followed by one of 1.3 milliards euro one in $2007^{28}$.

\section{Conclusions}

After reviewing the history of the implementation of factoring contract, we have been able to notice its stable motivated but at the same time insufficient evolution, on an average of $70 \%$, from one year to another. This has favored a gap of even 100 percentage points, respect to other emerging markets of Central and East Europe, such as Hungary, Turkey, Poland, Estonia and has also favored a considerable difference of 1000 percentage points or even more, respect to Western

\footnotetext{
${ }^{26}$ Factoring Chain International, Preliminary Report 2007.

${ }^{27}$ Factoring Chain International, Annual Raport, 2006.

${ }^{28}$ Official statement made by the president of the Factoring Company, Factoring Chain International, the Romanian subsidiary, Valentin Chirca, November 2006.
} 
Europe, represented by countries like France, Great Britain, Germany or Austria, where factoring is regarded as a traditional financing instrument. The potential of the Romanian market becomes even more obvious if we take into account the benefits given to adherents by means of credit contracts; the adherents represent juridical persons who need liquidities these days, in order to make their commercial activity but also their real and monetary exchanges more efficient, whereas on the other hand they found themselves in the situation of making appeal or being affected by the fact of resorting to products of structured financing, such as factoring, from the perspective of future collaboration relations with the agents. As we have been able to notice, the "internal factoring" package includes integrated services for operations regarding the financing and the administration of debentures, and, if necessary, for taking up the insolvency risk. The product offers a financing alternative to developing societies, to those already developed, but particularly to those which own debentures from internal deliveries.

The provisions in the field show that factoring offers to the adherent the possibility of turning a payment at the due time into a cashing at sight, on the basis of the property transfer of debentures to the partners. Thus, the adherent has immediately obtained the value corresponding to the delivered goods, so that his financial resources can be used according to the current necessities. Taking into account the statistic data illustrated above, we can notice the constant growth of factoring operations in the last years, so that we consider that there is an availability tendency towards this type of financing. Still, we believe that the product is not yet accessible to small adherents, on the one hand because they do not master quite well factoring services, and, on the other hand, because of the costs. In these circumstances, factors would do a good thing by organizing a mediation campaign, which would increase the banks' performance as factors and would contribute at the development of the local business.

Under the juridical aspect, there are no juridical thorough studies; practitioners or even bankers are less interested in the juridical dimension and even in the interferences of factoring with similar juridical institutions. Economists consider factoring only a financial "product" and treat it accordingly, as the interest in the profits seems to be more important. Sometimes not even doctrinarians are stricter, by using an inadequate terminology. For instance, the notion of discount has a strict juridical signification and applies only to credit titles, and not also to bills; the word "regress" is frequently replaced by the word "appeal", which from the juridical point of view has a fix sense, that is a method of questioning something.

The legislation is not either more comprehensive. There could be mentioned here the succinct incomplete regulation regarding this juridical instrument of a great interest, that we have already talked about. Of lege ferenda, given the major importance of factoring as a commerce financing technique, there are necessary some particular regulations, completely focusing on factoring, having as a result a rigorous terminology to include the concept of factoring and to be able to make up for the flaws already discussed. Equally important is to establish the attributes of the parts of the contract, that is deciding whether the factor must be a "qualified" subject (obligatory only a credit institution or a specialized financing institutions), to set out the factor and the adherent's obligations, to establish the juridical regime of the factoring with and without regress and also the circumstances allowing each of these two typologies.

Certainly, we are not suggesting some excessive regulations to discourage banking technique creation, which in its essence is mobile and dynamic and one step before the law. Given the fact that the debtor's notification currently must abide by the provisions of the Civil Code, of lege ferenda, the simplification of the procedure is absolutely necessary; therefore, the simple acknowledgement made by the adherent in a written form under private signature or even by an electronic channel, will become valid, as the law will provide the compulsory content of the notification.

Similarly to the Belgian law, this future normative act might provide the solution for endorsing the bills, so as to simplify the procedures required for transmitting debentures from the 
adherent to the factor and for ensuring the opposable feature of the assignment towards the assigned debtors, even if the bills do not have the juridical attribute of securities.

From the perspective of factoring development in harmony with the international practice, there can be taken into account the fact that a future law must consider not only the assignment of future debentures, but also the successive assignment of debentures, so as to create a proper evidence system containing the assignment dates; this evidence system should be separately identified within the Electronic Archive for Registering Movable Guarantees, and this can take place only by modifying the respective provisions of the Law no.99/1999 ${ }^{29}$. The law should provide what documents must accompany the debentures assigned by the adherent, the bill and the subrogating receipt, establishing at the same time the mandatory content of the latter.

Through the conclusions and proposals illustrated in this last subchapter, we are aiming at bringing a contribution, on the one hand, at underlining the great importance of improving the regulation framework of internal factoring contract, so that more and more people could resort to it, while on the other hand, at underlining the rapport advantages-disadvantages, at a quantitative and qualitative level, from the perspective of both the factor and the adherent. At the same time, we have brought into debate the internal factoring contract so as to make more popular within studies, researches and legislative initiatives this financing product, which is only now discovered by commerce operators and Romanian credit institutions, but which at the same time has a great potential for developing.

\section{Bibliogra phy}

Capatâna Octavian; Stefanescu Dreptul comertului international, $2^{\text {nd }}$ volume, Academia

Brândusa

Postolache Rada

Romana Publishing House, Bucharest, 1987

Turcu Ion

Vartolomei Brîndusa

Zaharciuc Elena

Drept bancar (Banking Law), Cartea Universitara P.House, Bucharest, 2005

Turcu Ion

Operatiuni si Contracte Bancare. Tratat de drept bancar, $5^{\text {th }}$

edition, amended, $2^{\text {nd }}$ volume, Lumina Lex Publishing House, Bucharest, 2004

Contractul de factoring, Lumina Lex Publishing House,

Bucharest, 2006

Contabilitatea societatilor bancare, Teora Publishing House, Bucharest, 2000

Factoring Chain International

Raport intermediary 2007

Acte Normative***

The Government Emergency Ordinance no. 99/2006 regarding credit institutions and the social capital adequacy, Off. Gaz., Part I, no.1027 of $27^{\text {th }}$ December 2006

$* * *$ Norms and Procedures "Factoring - a Product Presentation", Reiffeisen Bank Romania

$* * *$

$* * *$

The Government Ordinance no. 28/2006 regarding the regulation of some financial fiscal measures, Off. Gaz., Part I, no. 89 of 31 th January

The Law no.469/2002 regarding some measures for consolidating the contractual discipline, Off. Gaz., Part I. no.529 of $19^{\text {th }}$ July 2002, approved with amendments with the Law no. 647/2002, Off. Gaz., Part I, no. 99 of $13^{\text {th }}$ December 2002

\footnotetext{
${ }^{29}$ Off. Gaz., Part I, no. 263 of 27th May 2002.
} 